\title{
Xenophobia and class conflicts among Venezuelan migrants: an ethnographic study in the city of Ibarra, Ecuador
}

\author{
Jorge Mantilla \\ Universidad de Otavalo
}

\begin{abstract}
In recent years, the city of Ibarra, Ecuador has received nearly 10,000 migrants from Venezuela. In this municipality, the relations between locals and migrants are quite complex. In January 2019, a group of local residents physically assaulted several Venezuelan migrants (Case Diana). These acts had a xenophobic nature. Through ethnographic research, this article analyzes the social dynamics at this city in the months after these events. From the perspective of the Venezuelan population, one of the responses developed after these events consisted on a strategic construction of identities. On the one hand, they criticized homogenizing discourses, highlighting the group's own heterogeneity. On the other, they strengthened cooperation networks based on belonging to Venezuelan nationality. The article is aimed to shed light on intergroup dynamics in intermediate cities in the context of the ever-growing Venezuelan migration in Latin America.
\end{abstract}

Keywords: transnational migration, xenophobia, violence, Ecuador 